\title{
Malignant Lymph Node Neoplasm
}

National Cancer Institute

\section{Source}

National Cancer Institute. Malignant Lymph Node Neoplasm. NCI Thesaurus. Code C35812.

A primary or metastatic malignant tumor involving the lymph node. Lymphomas and metastatic carcinomas are representative examples. -- 2004 